\title{
Coupling biophysical processes and water rights to simulate spatially distributed water use in an intensively managed hydrologic system
}

\author{
Bangshuai Han ${ }^{1,2}$, Shawn G. Benner ${ }^{2}$, John P. Bolte ${ }^{3}$, Kellie B. Vache ${ }^{3}$, and Alejandro N. Flores ${ }^{2}$ \\ ${ }^{1}$ Natural Resources and Environmental Management, Ball State University, Muncie, IN, 47306, USA \\ ${ }^{2}$ Geosciences, Boise State University, Boise, ID, 83725, USA \\ ${ }^{3}$ Biological \& Ecological Engineering, Oregon State University, Corvallis, OR, 97333, USA \\ Correspondence to: Bangshuai Han (bhan@bsu.edu) and Alejandro N. Flores (lejoflores@boisestate.edu) \\ Received: 17 February 2017 - Discussion started: 13 March 2017 \\ Revised: 19 May 2017 - Accepted: 4 June 2017 - Published: 20 July 2017
}

\begin{abstract}
Humans have significantly altered the redistribution of water in intensively managed hydrologic systems, shifting the spatiotemporal patterns of surface water. Evaluating water availability requires integration of hydrologic processes and associated human influences. In this study, we summarize the development and evaluation of an extensible hydrologic model that explicitly integrates water rights to spatially distribute irrigation waters in a semi-arid agricultural region in the western US, using the Envision integrated modeling platform. The model captures both human and biophysical systems, particularly the diversion of water from the Boise River, which is the main water source that supports irrigated agriculture in this region. In agricultural areas, water demand is estimated as a function of crop type and local environmental conditions. Surface water to meet crop demand is diverted from the stream reaches, constrained by the amount of water available in the stream, the waterrights-appropriated amount, and the priority dates associated with particular places of use. Results, measured by flow rates at gaged stream and canal locations within the study area, suggest that the impacts of irrigation activities on the magnitude and timing of flows through this intensively managed system are well captured. The multi-year averaged diverted water from the Boise River matches observations well, reflecting the appropriation of water according to the water rights database. Because of the spatially explicit implementation of surface water diversion, the model can help diagnose places and times where water resources are likely insufficient
\end{abstract}

to meet agricultural water demands, and inform future water management decisions.

\section{Introduction}

\subsection{Background}

Increasing water demands for both agricultural and domestic consumption under the stress of climate change and increasing population represents a global environmental challenge (Vörösmarty et al., 2000). This increasingly limited hydrologic supply exists within the context of often extensive built hydrologic infrastructure. In turn, the management of that infrastructure is driven by complex social processes and decision making (Pahl-Wostl, 2007). Accordingly, projecting how climate change and human activities will alter water availability in the future requires developing models that can integrate human decision making and biophysical processes (Girard et al., 2015). This challenge is particularly acute in arid and semi-arid regions where water resources are typically limited and actively managed to support irrigationsupported agriculture (Falkenmark, 2013).

Explicit integration of both human and environmental processes in hydrologic modeling is an area of active investigation and a variety of approaches are being used. For example, Jakeman and Letcher (2003) introduced attempts in Australia to integrate between hydrological and economic models using a nodal network approach. Ahrends et al. (2008) devel- 
oped a coupled model system, consisting of a distributed hydrological model and an economic optimization model, communicating via model interfaces, to investigate regional interdependencies between irrigated agriculture and regional water balance in west Africa. Ferguson and Maxwell (2012) applied an integrated hydrologic model to compare effects of climate change and water management on terrestrial water and energy budgets of a representative agricultural watershed in the semi-arid southern Great Plains of the US. Willaarts et al. (2012) discussed win-win management solutions through societal evaluation of hydrological ecosystem services. Cai et al. (2013) evaluated potential hydrologic alterations of the Yangtze River under four scenarios of reservoir operation strategies by balancing human and environmental factors. Kirby et al. (2013) conducted a basin-wide simulation of flows and diversions for economic and policy analysis in the Murray-Darling Basin. Laniak et al. (2013) summarized recent progress and difficulties of integrated environmental modeling and urged that the global community of stakeholders transcend social and organizational boundaries, and pursue greater levels of collaboration.

In the arid and semi-arid regions, agriculture often relies heavily on irrigation and is typically the largest water use (Döll and Siebert, 2002; Shiklomanov, 2000). Irrigation diverts water to the originally dry lands, significantly altering the hydrological cycle. Because amount and timing of applied irrigation water is, ultimately, a local decision made by farmers for individual fields, it is particularly challenging to explicitly express these changes in a way that captures resulting spatially and temporally variable impacts.

A variety of approaches have been taken to express irrigation in hydrologic models. Many models rely on a simple soil-water balance module and empirically estimate the agricultural water demand. For example, Gisser and Mercado (1972) applied empirically estimated agricultural water demand into a hydrologic model in the Pecos River basin. Döll and Siebert (2002) developed a global irrigation model to calculate the irrigation water requirements depending actual and potential evapotranspiration rates. Cai et al. (2012) applied an irrigation diagnosis model to a regional irrigation system in the Yangtze River basin to analyze the local water budget. These models are advantageous for hydrologic-economic assessment but typically discount some details of the physical system. Physically based models can simulate processes influencing the water balance, including crop growth, irrigation, fertilizer applications, and solute transport. Examples include the soil-water-atmosphereplant (SWAP) model (Dam et al., 1997; Droogers et al., 2000), the Environmental Policy Integrated Climate (EPIC) model (Gassman et al., 2005), and the CropSyst model (Stöckle et al., 2003). Generally, these models are operated as point-scale models and do not express processes in a spatially explicit manner. With expanded computational capacity and the progress of geographic information systems (GIS), increasing interest has been devoted to the integration of agricultural-based models with spatially distributed hydrologic models, e.g., VIC-CropSyst (Stöckle et al., 2014) and GEPIC (Liu et al., 2007). Generally, the commonly used approach in irrigation modeling is to set soil moisture to field capacity or soil saturation or set a fixed evapotranspiration rate in irrigated areas (Leng et al., 2014), which can lead to inaccurate water budget and an inability to represent irrigation in a more realistic way. It is also a common practice to assume unlimited water supply when considering the sources and availability of irrigation water, which does not reflect the truth in many water-limited environments (Sorooshian et al., 2012). As such, we are aiming to incorporate irrigation activities in our model in a more realistic way.

In the western US, water is mostly allocated according to legally defined water rights following the Prior Appropriation Doctrine, which basically defines that water rights are determined by priority of beneficial use; historical use of water creates a right to the water. This means that the irrigation amount is dependent not only on physically defined water availability but also on constraints dictated by legally defined water rights. In these systems, water use for irrigation is, therefore, the product of both environmental constraints (e.g., basin-scale water availability and evaporative demand) and human constraints through water rights allocations. Accordingly, water rights represent an important and well-defined constraint on irrigation water use in these systems. However, few models consider the influence of water rights on the redistribution of water. The state of Texas has implemented a modeling system called Water Rights Analysis Package (WRAP) to assess water availability and reliability of water resources with local water rights (Wurbs, 2005a, b), but the model is not fully spatially distributed and the model functions on a monthly scale.

In this study, we demonstrate an approach that integrates water diversion for irrigation based on water rights within a physically based model of hydrologic processes. We outline the development of the core elements of both the biophysical and social system components of the model that appear critical to represent the redistribution of water within the study area.

\subsection{Study area}

The Treasure Valley area, located in southwest Idaho, is the most populous region of Idaho and contains its three largest cities, Boise, Nampa, and Meridian (Fig. 1), but is also home to an extensive irrigation-supported agriculture. The area collectively comprises about $40 \%$ of state's total population, with an area of $3323 \mathrm{~km}^{2}$. Farmland occupies about $40 \%$ of the total landscape, with an area of $1289 \mathrm{~km}^{2}$, and relies heavily on irrigation through about $1700 \mathrm{~km}$ of constructed canals.

The climate generally consists of a semi-arid Mediterranean pattern with a hot, dry summer and cold, wet winter, with strong spatial and temporal fluctuations in temperature 


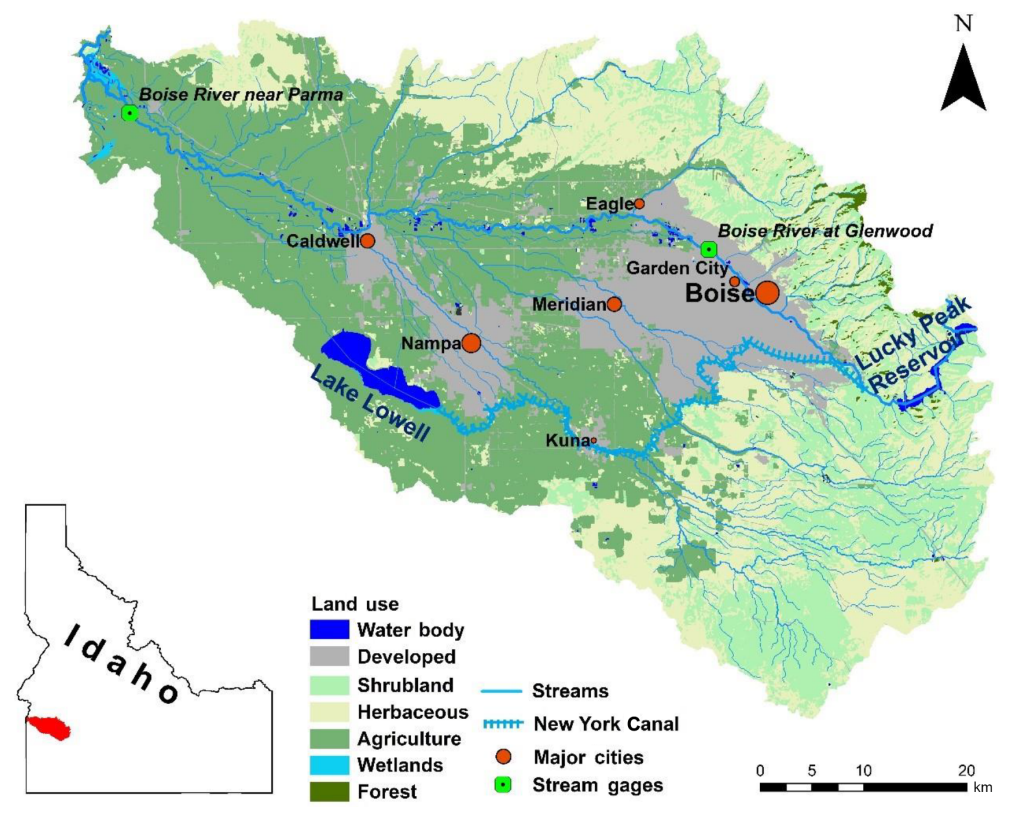

Figure 1. Study area: the Treasure Valley.

and rainfall. Annual rainfall varies substantially within the basin from $\sim 700 \mathrm{~mm}$ in the northeast foothills to $\sim 200 \mathrm{~mm}$ in the southwest at Lake Lowell, with a historical average of about $296 \mathrm{~mm} \mathrm{yr}^{-1}$ at Boise Air Terminal weather station. About $50 \%$ of the total precipitation occurs during the nonirrigation season. Like many intensively managed landscapes in semi-arid and mountainous regions of the world, a series of reservoirs upstream of the Treasure Valley regulate and homogenize flows out of the upper basin into the Boise River. The lowermost of these reservoirs, Lucky Peak, is operated jointly by the US Army Corps of Engineers and the Bureau of Reclamation for purposes of flood control and irrigation water supply. From the Lucky Peak Reservoir, the Boise River exits the mountains and flows about $103 \mathrm{~km}$ (64 miles) northwestward through the Treasure Valley to its confluence with the Snake River. The Treasure Valley is bounded to the north by the Boise foothills and to the south by the Snake River. A number of canals and diversion dams have been built along the Boise River water course to allocate water resources. Among the largest of these canals is the New York Canal that diverts water directly from the Boise River about $1.6 \mathrm{~km}$ downstream of the Lucky Peak dam. During non-irrigation season, the New York Canal carries a portion of the water to fill Lake Lowell, a reservoir within the Treasure Valley area, for use during the irrigation season. During irrigation season, the New York Canal carries a significant portion of the water from the Boise River and diverts it into distributary canals within the agricultural areas of the Treasure Valley. With the benefit of irrigation, population in the Treasure Valley has been growing rapidly and consistently since the 1870s. Urban growth and increasing irrigation activities drive land use change and reallocation of water resources. Despite the im- portance of water resources and potential threats of water scarcity, there have been limited integrative studies regarding water availability and scarcity in this area. The Idaho Department of Water Resources (IDWR) conducted the Treasure Valley Hydrologic Project, which started in 1996, aiming to develop a better understanding of water resources in the Treasure Valley and to evaluate changes in regional and local groundwater conditions (IDWR, 2017). Supported by this project, Petrich (2004b) characterized and simulated groundwater flow in the lower Boise River basin, and analyzed the water budgets for the regional aquifer system based on 1996 and 2000 calendar-year inflow and outflow estimates (Petrich, 2004b; Urban and Petrich, 1996). Local, state, city, and some federal agencies have also supported or conducted a few water demand studies that characterized the local land use and the associated domestic, commercial, municipal, and industrial water demands. However, most of these studies are conducted at the conceptual level by estimating total water budgets. Xu et al. (2014) conducted a hedonic analysis to estimate the response of agricultural land use to water supply information under the Prior Appropriation Doctrine. Their results are informative at the scale of the entire Treasure Valley but also lack spatiotemporally dynamic components that could be used to reveal particular locations in space and periods in time where water demand and supply are out of balance. This research seeks a practical integration of the spatiotemporal detail that is available in the water rights database with the local spatiotemporal dynamics of surface water hydrology. An important outcome of this study is an extensible modeling framework that can serve as a foundational tool to capture and evaluate the complex interactions 
between the social and biophysical systems related to water use in an integrated way.

\section{Methods}

\subsection{Envision platform and datasets}

The model developed in this study is based on the Envision modeling tool, a spatially explicit integrated simulation platform that can be used to integrate elements of biophysical and social systems (Bolte et al., 2007; Inouye, 2014). Envision provides a geospatial software framework to coordinate the interoperation of component models used to represent essential processes and properties of the coupled social and biophysical systems being simulated. Envision has been used in a variety of projects, e.g., to develop alterative future scenarios under three growth management strategies for the Puget Sound region in Washington, USA (Bolte and Vache, 2010), construct a land use/land cover (LULC) agent based modeling for the Motueka catchment, Australia (Montes de Oca Munguia et al., 2009), evaluate potential impacts of climate change on vegetation cover in the Willamette River basin, Oregon, USA (Turner et al., 2015), and understand coupled natural and human systems on fire-prone landscapes (Barros et al., 2015).

In Envision, the spatial domain is represented by a collection of polygons, called integrated decision units (IDUs). Each IDU polygon is associated with important geospatial attributes characterizing both biophysical and social properties (e.g., elevation, soil type, land use, population density, disturbance history, water rights code, irrigation decision). The IDU forms the fundamental spatial unit for integrated decision making in Envision. The process of creating the IDU computational domain is somewhat ad hoc and iterative but is meant to balance the competing demands of fidelity to spatial heterogeneity and associated computational cost. The IDU computational domain was constructed through a process that initially converted raster-based LULC information into a polygon layer by grouping adjacent sets of pixels with similar land use/land cover classes into polygons. Small polygons derived from a single LULC pixel within a larger polygon of a different land use/land cover class (i.e., with an area of $900 \mathrm{~m}^{2}$ or less) were identified and deleted. The final constructed computational domain for the Treasure Valley consists of 32508 IDUs (polygons).

A variety of datasets is required to build the model (Table 1), among which, spatial heterogeneity in the model is mainly reflected by three spatially explicit datasets: land cover, elevation, and meteorological inputs. The land cover data are collected from the Nation Land Cover Dataset, using the data of 2011. The elevation data are collected from the National Elevation Dataset with a spatial resolution of $30 \mathrm{~m}$. The climate dataset is a spatially and temporally complete, high-resolution $(4 \mathrm{~km})$ gridded dataset of surface me- teorological variables created by bias-correcting daily and sub-daily mesoscale reanalysis and assimilated precipitation from the NLDAS-2 using monthly temperature, precipitation and humidity from the Parameter-elevation Regressions on Independent Slopes Model (PRISM; Abatzoglou and Brown, 2012). The stream network is defined from the NHDPlus V2 dataset, which represents stream networks as node-based line coverages. Segments between nodes are considered to be stream reaches and each IDU is assigned a stream reach for the purposes of simulating hydrologic routing. Artificial channels such as irrigation canals and drains are explicitly represented. However, as discussed below, they are functionally captured using the WaterMaster module, which simulates the allocated water based on water rights.

\subsection{Hydrologic processes}

In this study, we employ the module called Flow with a slightly changed Hydrologiska Byråns Vattenbalansavdelning (HBV) (Bergström, 1995; Woodsmith et al., 2007) plugin to represent hydrologic processes. Human interventions include reservoir operations and agricultural irrigation which is simulated by another Flow plug-in called WaterMaster. The primary focus of the current paper is to develop a framework to incorporate human activities, mainly irrigation, at the watershed scale and provide a solid basis for future integrated scenario projections.

Within Envision, the HBV model is applied in a semi-distributed way to delineated hydrologic response units (HRUs) within the study domain affording the use of spatially distributed datasets such as daily gridded meteorological inputs, land cover, and elevation information (Inouye, 2014). Within the model, HRUs are delineated by aggregating adjacent IDUs that are associated with a common LULC and similar elevation, and 4456 HRUs are composed. Hydrologic processes are simulated at the HRU level, with fluxes being distributed uniformly to the IDUs within the HRU.

Here, we briefly describe the slightly changed HBV model (Fig. 2). A catchment in the model is conceptualized as a series of linked reservoirs and is divided into six layers in this study: snowpack, melt, irrigated soil, non-irrigated soil, upper groundwater, and lower groundwater.

Runoff from the HRUs from different layers is then routed to streams using linear outflow equations. The water balance equation in Flow (HBV) can be described as

$P-\mathrm{ET}-Q=\frac{\mathrm{d}}{\mathrm{d} t}[\mathrm{SP}+\mathrm{SM}+\mathrm{UZ}+\mathrm{LZ}+$ lakes $]$,

where $P$ is precipitation; ET is evapotranspiration; $Q$ is runoff; SP is snow storage; SM is soil moisture storage; UZ is upper groundwater storage; $\mathrm{LZ}$ is lower groundwater storage; "lakes" indicate lake storage.

The model simulates daily discharge using daily rainfall, temperature, and potential evapotranspiration as inputs. Precipitation is simulated to be either snow or rain depending on 
Table 1. Datasets used in the model.

\begin{tabular}{|c|c|c|c|c|}
\hline Input data & Data sources & $\begin{array}{l}\text { Dates/spatial } \\
\text { resolution }\end{array}$ & $\begin{array}{l}\text { Used in model } \\
\text { components }\end{array}$ & URL \\
\hline $\begin{array}{l}\text { Land } \\
\text { use/land } \\
\text { cover }\end{array}$ & $\begin{array}{l}\text { National } \\
\text { Land cover } \\
\text { Dataset }\end{array}$ & $2011 / 30 \mathrm{~m}$ & Evapotranspiration & http://www.mrlc.gov/nlcd2011.php \\
\hline $\begin{array}{l}\text { Streams/ } \\
\text { canals/water } \\
\text { bodies }\end{array}$ & NHDPlus V2 & 2012 & $\begin{array}{l}\text { Building stream } \\
\text { network and flow } \\
\text { routing }\end{array}$ & http://www.horizon-systems.com/nhdplus/NHDPlusV2_17.php \\
\hline $\begin{array}{l}\text { Downscaled } \\
\text { climate } \\
\text { data }\end{array}$ & $\begin{array}{l}\text { U. of Idaho } \\
\text { METDATA }\end{array}$ & $\begin{array}{l}2006-2013 / \\
4 \mathrm{~km}\end{array}$ & Evapotranspiration & http://cida.usgs.gov/thredds/catalog.html?dataset=cida.usgs.gov/thredds/UofIMETDATA \\
\hline $\begin{array}{l}\text { Daily } \\
\text { stream } \\
\text { discharge }\end{array}$ & $\begin{array}{l}\text { USGS } \\
\text { Instantaneous } \\
\text { Data archive }\end{array}$ & 2006-2013 & $\begin{array}{l}\text { Hydrology model } \\
\text { calibration and } \\
\text { validation }\end{array}$ & http://nwis.waterdata.usgs.gov/nwis/rt \\
\hline $\begin{array}{l}\text { Digital } \\
\text { elevation } \\
\text { model }\end{array}$ & NED & $\mathrm{n} / \mathrm{a} / 30 \mathrm{~m}$ & Building HRU & http://nationalmap.gov/elevation.html \\
\hline $\begin{array}{l}\text { Water } \\
\text { rights }\end{array}$ & $\begin{array}{l}\text { Idaho Dept. } \\
\text { of Water } \\
\text { Resources }\end{array}$ & 2010 & $\begin{array}{l}\text { Irrigation } \\
\text { (WaterMaster) }\end{array}$ & http://www.idwr.idaho.gov/ftp/gisdata/Spatial/WaterRights \\
\hline
\end{tabular}

Here, n/a indicates "not applicable".

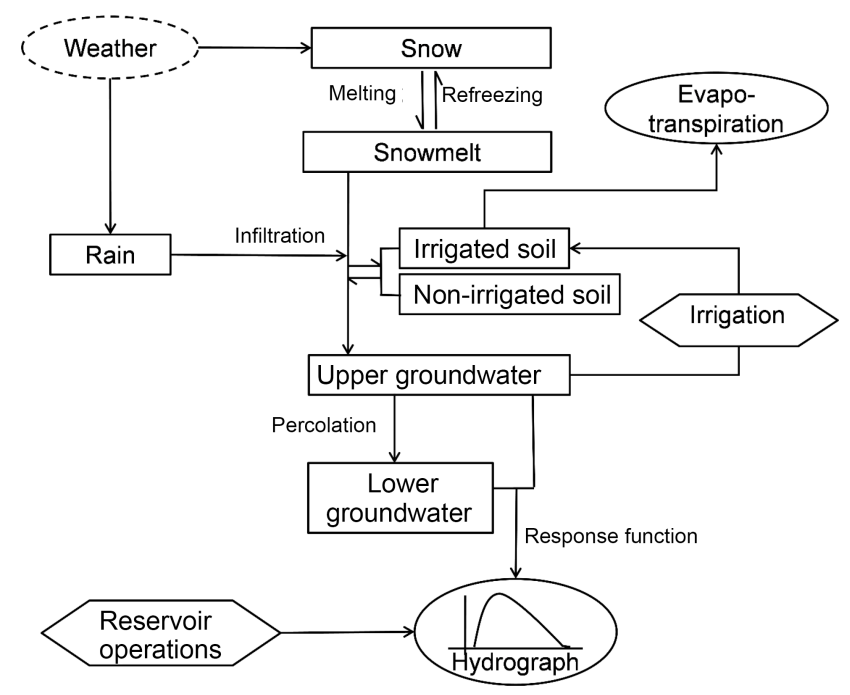

Figure 2. Flowchart of the Flow module in Envision. Note the human activities influencing water availability. Water is distributed by the local water rights data (irrigation activities) and is also constrained by the reservoir operations.

whether the temperature is above or below a threshold temperature (TT). Rainfall and snowmelt are then divided into water either filling the conceptual soil layer or recharge into groundwater depending on the current soil moisture, field capacity (FC), and the parameter " $\beta$ " (Eq. 2).

$F=\left(\frac{\text { Soil Water }}{\mathrm{FC}}\right)^{\beta}$ where $F$ is the fraction of rain or snow. Evapotranspiration (ET) is simulated using the FAO56 Penman-Monteith method as specified by the UN Food and Agriculture Organization (FAO) in paper number 56 (Allen et al., 1998) and in Allen and Robison (2007). Generally, a crop coefficient $\mathrm{K}_{\mathrm{c}}$ is developed to simplify and standardize the calculation and estimation of crop water use, and is an integration of the effects of crop properties and soil properties. As plants grow and develop, $\mathrm{K}_{\mathrm{c}}$ varies over time and the values are obtained from AgriMet Pacific Northwest Cooperative Agricultural Weather Network. The potential ET of a specific crop, $\mathrm{ET}_{\mathrm{c}}$, is then calculated as in Eq. (3):

$\mathrm{ET}_{\mathrm{c}}=K_{\mathrm{c}} \cdot \mathrm{ET}_{\mathrm{r}}$,

where $\mathrm{ET}_{\mathrm{r}}$ is the reference evapotranspiration rate, the evapotranspiration rate for a standardized vegetated surface corresponding to a living, agricultural crop (usually using fullcover alfalfa). For simplicity at this framework building stage, we do not include detailed crop categories and crop rotation schedules. Rather, we use the crop coefficients of alfalfa for all agricultural land use in the region due to the fact that most of the agricultural land in the Treasure Valley is fully irrigated. Crop coefficients are assigned for nonagricultural lands based on crop categories with similar physical characteristics as an approximation (Table 2). Detailed evapotranspiration calculation methods could be found in Allen and Robison (2007). Actual ET in the model is constrained by soil moisture at each HRU, as simulated in each daily time step. The soil box is subdivided into two layers/fractions, irrigated soil and non-irrigated soil, to help facilitate water to be irrigated and evaporated from the irrigation areas. The response function consisting of two or 


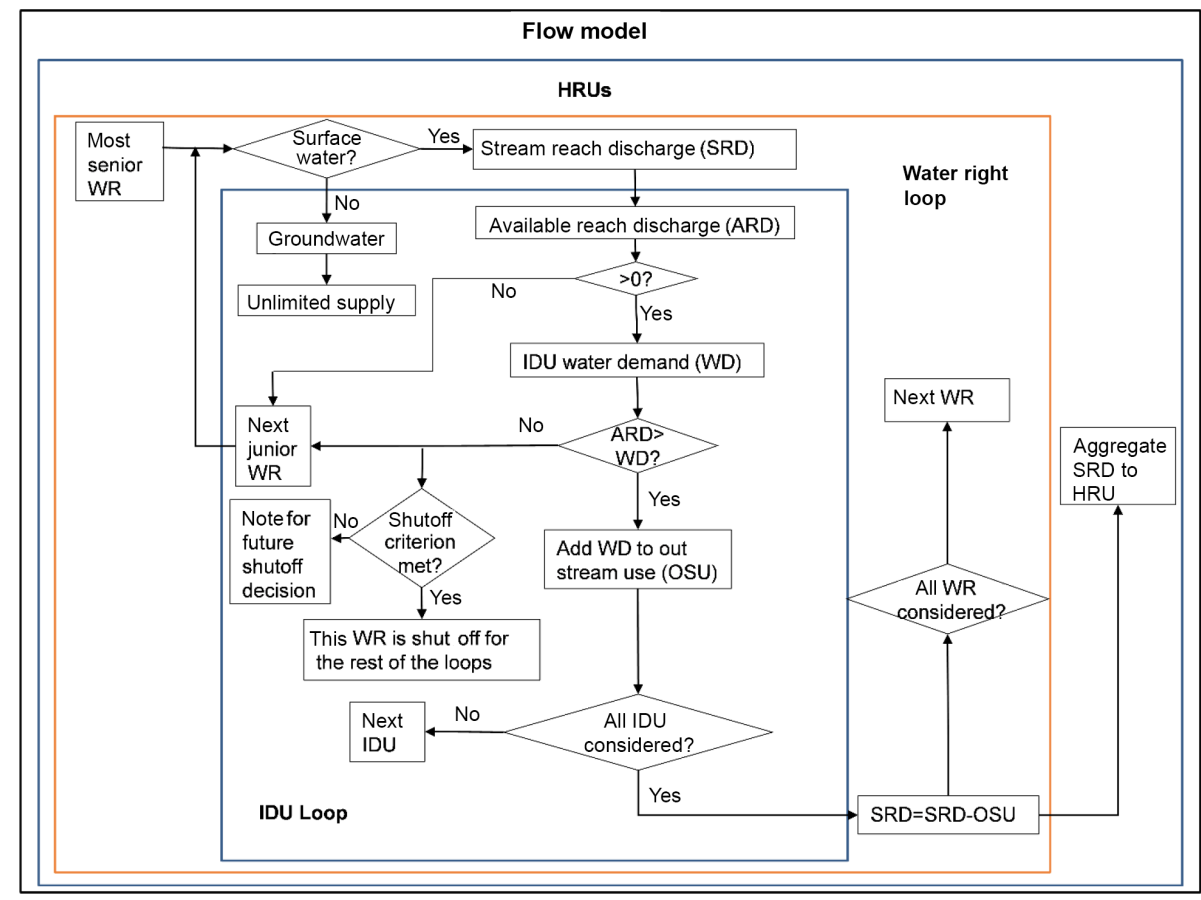

Figure 3. WaterMaster loop that makes use of the local water rights data for irrigation.

Table 2. Crop categories used to approximate the land use categories in the ET calculation.

\begin{tabular}{ll}
\hline Land use category & Approximated crops in ET calculation \\
\hline Agricultural & Alfalfa \\
Developed land & Bare land \\
Forest & Poplar \\
Shrubland & Sagebrush \\
Herbaceous & Average of cheatgrass, bunch grass, and \\
& bromegrass \\
\hline
\end{tabular}

three linear outflow equations depending on whether or not recharge in the upper groundwater box (SUZ) is above a threshold value (UZL) then transforms excess water from the soil layer to runoff (Eqs. 4-6).

$Q_{0}=K_{0} \cdot(\mathrm{SUZ}-\mathrm{UZL})$

$Q_{1}=K_{1} \cdot \mathrm{SUZ}$

$Q_{2}=K_{2} \cdot \mathrm{SLZ}$,

where SUZ is the recharge (water depth) at the upper groundwater zone that is simulated at each time step, UZL is a threshold value, and SLZ is the recharge (water depth) at the lower groundwater zone that is simulated at each time step. If SUZ is greater than or equal to UZL, then the total water that is routed to runoff is the summation of $Q_{0}, Q_{1}$, and $Q_{2}$. If SUZ is less than UZL, then the total water that is routed to runoff is the summation of $Q_{1}$ and $Q_{2}$.

\subsection{Simulation of water rights}

Irrigated water allocation is simulated via a module called WaterMaster (Fig. 3) that adheres to publicly available water rights data in Idaho in accordance with the Prior Appropriation Doctrine (Hutchins, 1977; Xu et al., 2014). In this study, surface water and groundwater irrigation activities are simulated based on the water rights data updated in 2012 by IDWR. Each water right is associated with four attributes that are of critical importance to this study: (1) the place of use (POU), (2) the point of diversion (POD), (3) the priority date, and (4) the appropriated diversion rate.

The POU data are used to identify IDUs in the study domain with surface water and/or groundwater rights. For surface water rights, water is extracted from the stream reach closest to the POD associated with that water right. In most cases in the Treasure Valley, the PODs are located along irrigation canals not explicitly being simulated, and the PODs are assumed to be the point at which water is originally diverted from a natural watercourse (a majority originally diverted from the Boise River due to its seniority and largest diversion capacity) into the associated supply canal system. The priority date of each water right determines whether or not water can be diverted from the stream reach associated with the POD and applied to the IDUs within a POU as irrigation on a particular date during the simulation. On each day of the simulation, WaterMaster determines all water rights active on that date and, based on the allocation rates of those water rights, determines the maximum flow of water that may be diverted at each stream reach associated with 
one or more PODs. The irrigation water demand at the POU is computed as the potential evapotranspiration for the agricultural IDUs within each POU with a composite loss coefficient which is currently set based on an overall estimation of $60 \%$ water loss from the original diversion to ultimate crop use. The coefficient was roughly estimated based on a local study of irrigation management in 1999 and the proposed potential improvement in the study to reflect the current irrigation efficiency (Huter et al., 1999). To simplify the model, the amount of diverted water is applied to the places of use for evaporation or infiltration, and the amount of usable water for crops considers the loss coefficient. The amount of water demanded for diversion at the stream reach is then computed as the sum of water demand for all POUs associated with a POD along that reach. If there is sufficient streamflow to satisfy demand, the amount of water diverted equals the total demand. If there is insufficient streamflow in the reach to satisfy demand, then water rights must be curtailed. Water rights with highest seniority (i.e., earliest priority date) are satisfied and streamflow is reduced by the allocation rate associated with that right, followed by the next most senior water right, and so forth until there is insufficient streamflow to meet demands of water right. At this point, that water right and all the more junior rights are curtailed only for the current date and will resume water use whenever there is abundant streamflow later in the year. This approach simulates the effect of canals and distributaries without explicitly simulating the hydraulics of canal flow. Specifically, water is diverted from an actual place of diversion as captured by the IDWR database and applied to a place of use in accordance with the water rights database. For groundwater rights, we assume unlimited groundwater source as of now due to the fact that groundwater resources are abundant for the withdrawal rates in the Treasure Valley (Petrich, 2004a). On the valley-wide basis, the volume of groundwater pumped during the year accounts for only 15 to $20 \%$ of the total groundwater recharge (Urban and Petrich, 1996). Groundwater in the Treasure Valley is mainly recharged from the seepages from the canal system, flood irrigation, and precipitation. Use of groundwater for irrigation is common, although surface water rights comprise a much larger proportion of agricultural water use on a volume basis in the Treasure Valley.

Here, we would like to define several important terms used below:

- The allocated water indicates the amount of water that is met and diverted to the corresponding place of use in the model.

- The unsatisfied water indicates the amount of water that is not met for the corresponding place of use in the model.

- The appropriated diversion rate is calculated based only on the POD rates and the corresponding POUs, and reflects the amount of water that is potentially usable based on the existing water rights maximum rates while it ignores priority dates and physical constraints. It is calculated upon the water rights dataset instead of being simulated by the model.

\subsection{Reservoirs and boundary condition}

Reservoirs are considered part of the stream network in Envision. The location and physical constraints of the Lucky Peak Reservoir and Lake Lowell's dams are set up based on the data collected from the Hydromet database (Table 1). The Lucky Peak Reservoir receives water drained from the watersheds upstream of the Boise River and is the main water resource for the Treasure Valley. The historical inflows to the Lucky Peak Reservoir are used as inflow boundary conditions for the model. Lake Lowell is an off-stream reservoir formed by three earth fill dams enclosing a natural depression in the southwest Treasure Valley. The reservoir naturally drains water and is also filled during the non-irrigation season by diversions at the Boise River Diversion Dam through New York Canal. In this study, we simplify the reservoir operations by setting the maximum and minimum flows at a downstream control point of each reservoir (Boise River at Diversion Dam for Lucky Peak Reservoir and Boise River near Parma River for Lake Lowell) based on historical daily extreme values to regulate the extreme flow released from the reservoirs. This setup is efficient while still simulating the normal operation of the Boise Project Board of Control. The operation basically aims to control flood in the Boise River for the safety of the city, uses the natural river flows until the Boise River falls to a certain level, and then switches to water stored in reservoirs and provides users a certain allotment of water they can use for the irrigation season. As such, by setting up maximum and minimum daily flows, the reservoirs are designed to release water in the dry seasons and control flooding water in the snowmelt season of the area.

\subsection{Model calibration and validation methods}

The reliability of many hydrological models is dependent on calibration, which is the process of finding an optimal set of parameters that enable the model to closely match the behavior of the real system it represents (Gupta et al., 1998). We calibrated the model based on the Nash-Sutcliffe coefficient (Eq. 7) between the observed and simulated streamflows at two USGS gages - Boise River at Glenwood and Boise River near Parma, Idaho.

The Nash-Sutcliffe coefficient is calculated as

$E=1-\frac{\sum_{t=1}^{T}\left(Q_{\mathrm{obs}}^{t}-Q_{\mathrm{sim}}^{t}\right)^{2}}{\sum_{t=1}^{T}\left(Q_{\mathrm{obs}}^{t}-\overline{Q_{\mathrm{obs}}}\right)^{2}}$,

where $Q_{\text {obs }}$ is the observed discharge, $Q_{\text {sim }}$ is the simulated discharge, $t$ is the time step at calculation, and $\overline{Q_{\text {obs }}}$ is 
Table 3. Parameters used, the range considered for calibration, and the calibrated values.

\begin{tabular}{|c|c|c|c|c|c|}
\hline Routine & Parameter & Description & Units & $\begin{array}{r}\text { Range } \\
\text { considered }\end{array}$ & $\begin{array}{r}\text { Calibrated } \\
\text { value }\end{array}$ \\
\hline \multirow{5}{*}{$\begin{array}{l}\text { Snow } \\
\text { routine }\end{array}$} & TT & Threshold temperature & ${ }^{\circ} \mathrm{C}$ & $-2.0-2.0$ & 0.4 \\
\hline & CFMAX & $\begin{array}{l}\text { Degree-day factor governing } \\
\text { maximum snowmelt rate }\end{array}$ & $\mathrm{mm}^{\circ} \mathrm{C}^{-1} \mathrm{day}^{-1}$ & $1.0-6.0$ & 3.6 \\
\hline & SFCF & Snowmelt correction factor & - & $0.5-3.0$ & 2.2 \\
\hline & CFR & Refreeze coefficient & - & 0.05 & 0.05 \\
\hline & $\mathrm{CWH}$ & $\begin{array}{l}\text { Water holding capacity of } \\
\text { snowpack }\end{array}$ & - & 0.1 & 0.1 \\
\hline \multirow{4}{*}{$\begin{array}{l}\text { Soil and } \\
\text { evaporation } \\
\text { routine }\end{array}$} & FC & $\begin{array}{l}\text { Maximum depth of water in } \\
\text { soil water reservoir }\end{array}$ & $\mathrm{mm}$ & 395 & 395 \\
\hline & LP & $\begin{array}{l}\text { Soil moisture value above } \\
\text { which actual ET equals PET }\end{array}$ & $\mathrm{mm}$ & 200.0 & 200 \\
\hline & WP & $\begin{array}{l}\text { Wilting point in soil for ET to } \\
\text { occur }\end{array}$ & $\mathrm{mm}$ & 147 & 147 \\
\hline & BETA & Shaping coefficient & - & $1.0-6.0$ & 2.6 \\
\hline \multirow{5}{*}{$\begin{array}{l}\text { Ground- } \\
\text { water and } \\
\text { response } \\
\text { routine }\end{array}$} & PERC & Percolation coefficient & per day & $0.1-10.0$ & 6.6 \\
\hline & UZL & Threshold for $K_{0}$ to outflow & $\mathrm{mm}$ & $10.0-500.0$ & 240.7 \\
\hline & $K_{0}$ & Recession coefficient & per day & $0.1-1$ & 0.7 \\
\hline & $K_{1}$ & Recession coefficient & per day & $0.01-1.0$ & 0.07 \\
\hline & $K_{2}$ & Recession coefficient & per day & $0.0001-1.0$ & 0.0002 \\
\hline
\end{tabular}

the mean observed discharge over the entire run. The NashSutcliffe coefficient can range from $-\infty$ to 1 (perfect match). An efficiency of negative value indicates that the mean value of the historical observations would be a better predictor than the hydrologic model.

Most parameters used in the model are estimated using a Monte Carlo approach. The data from 2006 to 2009 are used for calibration processes and from 2010 to 2013 for validation purposes. The time period is relatively short; however, it contains typical wet years $(2006,2008,2011,2012)$ and dry years $(2007,2013)$. For each run, each parameter value was randomly selected from a uniform distribution; the minimum and maximum values of these distributions, listed in Table 3, are generally adopted from Sælthun (1996), Lawrence et al. (2009), Abebe et al. (2010), and Inouye (2014). We simultaneously vary the values of the parameters within their target ranges and run the model 1000 times. Then the bestfit parameter sets are selected through an assessment of the fit of simulated to observed runoff data based on visual inspection of fit and the Nash-Sutcliffe coefficient $(E)$ between the observed discharge and the simulated discharge. The parameters are conceptually based on physical parameters of the system. Although they are actually effective parameters that fit the model through calibration and do not necessarily represent actual physical properties, it would be beneficial to get physically representative values whenever possible. In this calibration process, we calibrate 9 parameters of the total 14 parameters, while setting 5 parameters constant to save computational time. The FC and WP val- ues were adopted from the SSURGO dataset from the Natural Resources Conservation Service (SSURGO, 2017). Since LP, CFR, and CWH are not sensitive to model performance (Seibert, 1997), a reasonable LP value was set based on local soil conditions, and CFR and CWH were held constant.

\section{Results}

In this section, the calibration and validation results of the hydrological module are presented, the water rights dataset is summarized, and the irrigation water use and water scarcity from 2006 to 2013 are analyzed.

\subsection{Calibration and validation}

The model was calibrated and validated against historical observations through discharge at two USGS gaging stations (Boise River at Glenwood and Boise River near Parma) and at the New York Canal. These two calibration targets reflect influences of different processes. The upper gaging station (Glenwood) is just downstream from the New York Canal, the primary point of extraction but is upstream of the majority of return flow to the Boise River, which is primarily in the lower portion of the river. In contrast, the Parma gaging station is located just above the confluence with the Snake River and is downstream of both the majority of the extraction and return flows. Accordingly, model results that successfully match the Glenwood gage provide a good indication of the model's capacity to simulate water consumption 

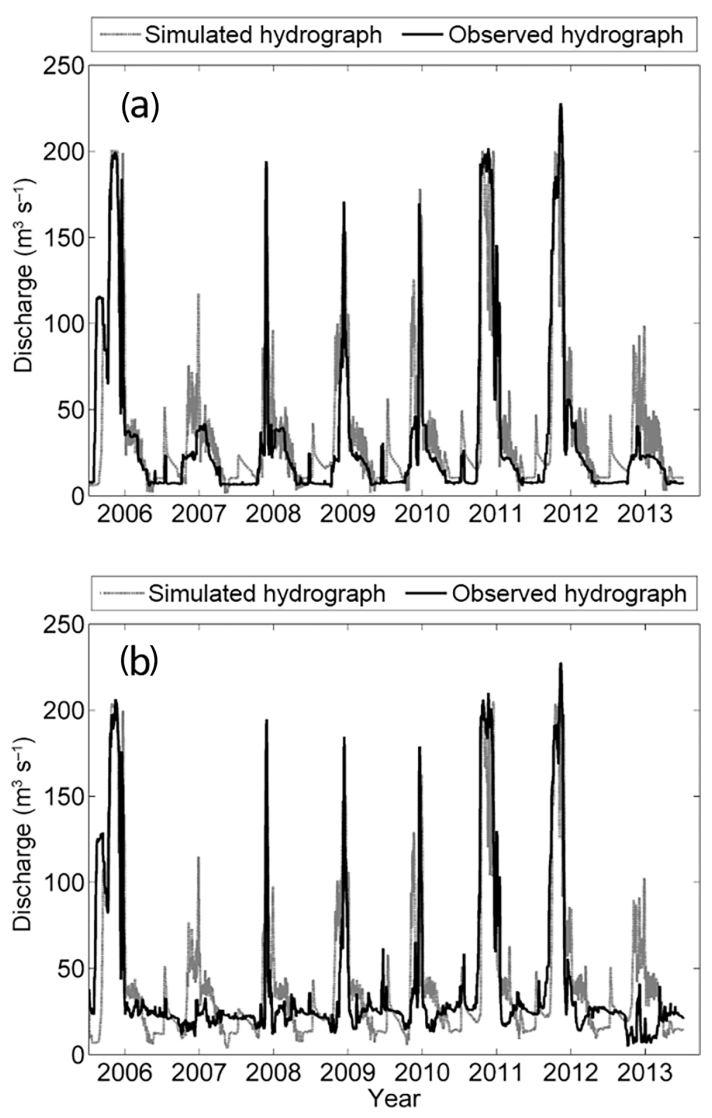

Figure 4. Simulated discharge and the observations during the calibration (2006-2009) and validation (2010-2013) periods at the Glenwood station of the Boise River (a) and Parma station of the Boise River (b).

and associated removal, while comparing the model results to the Parma gage is more strongly influenced by the model's capacity to capture return flow.

A plot of the simulated and the observed flows at these two USGS sites for the calibration period (2006-2009) and the validation period (2010-2013) is shown in Fig. 4. The model effectively captures the major high and low flow events, the extreme values of which are constrained by the downstream control points. For example, at Glenwood, the annual discharge is clearly dominated by three periods associated with late winter or spring high flows, irrigation season flows, and fall-winter low flows. The coefficient $E$, which is a criterion to estimate the goodness of fit between observational data and simulated data, is 0.82 during the calibration period and 0.67 during the validation period at the Glenwood site, and 0.69 during the calibration period and 0.62 during the validation period at the Parma site. The good fit to the Parma gage suggests the model captures return flow particularly well. We also compare the amount of water diverted to the New York Canal with the simulated results and find a good match with a correlation coefficient of 0.92 (Fig. 5),

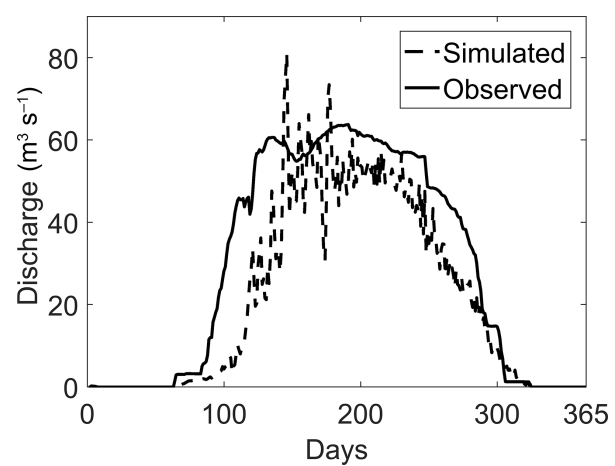

Figure 5. Simulated irrigation amount and the observations averaged over the years 2006-2013 at the New York Canal. The solid line shows the observed daily discharge rate in $\mathrm{m}^{3} \mathrm{~s}^{-1}$ and the dashed line shows the simulated discharge in $\mathrm{m}^{3} \mathrm{~s}^{-1}$.

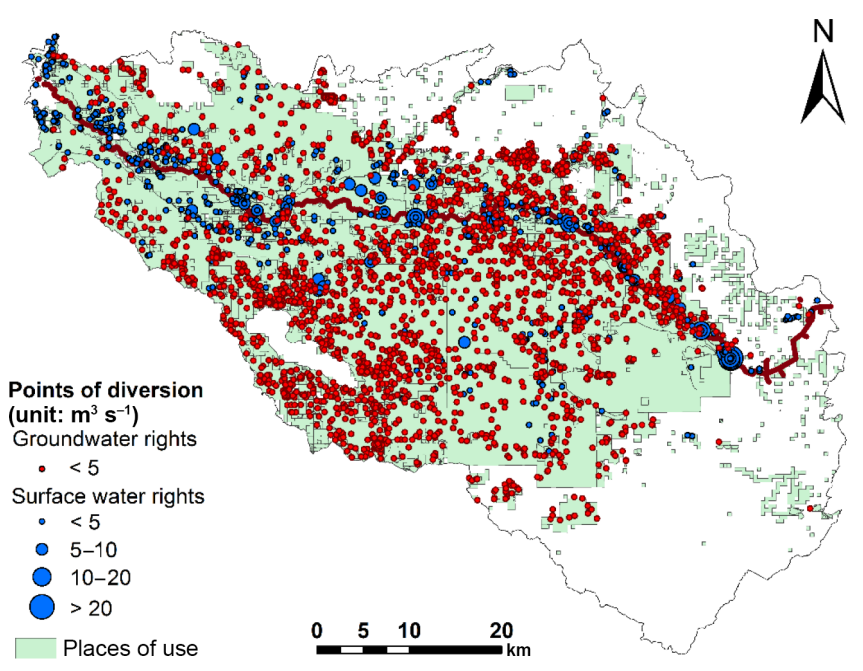

Figure 6. The spatial distribution of the points of diversion (PODs) for irrigation purpose and the maximum allowed diversion rates.

indicating that the model does a good job of capturing the diversion amount from the Boise River.

\subsection{A summary of the irrigation water rights}

In the Treasure Valley, surface water is the main water source for irrigation, despite many more PODs for groundwater. Currently, there are 22217 PODs and 21492 POUs in the study area, among which 4838 PODs and 3859 POUs are appropriated for the irrigation use (Fig. 6). In the following analysis, all water rights are irrigation water rights unless stated otherwise. Within the database of all water rights, $78 \%$ of the PODs use groundwater as a water source, and only $22 \%$ use surface water as a water source. However, surface water is still the main water source with regard to the amount of irrigated water supply. Surface water PODs are mainly located along the Boise River, usually with a relatively higher maximum allowed diversion rate per POD 


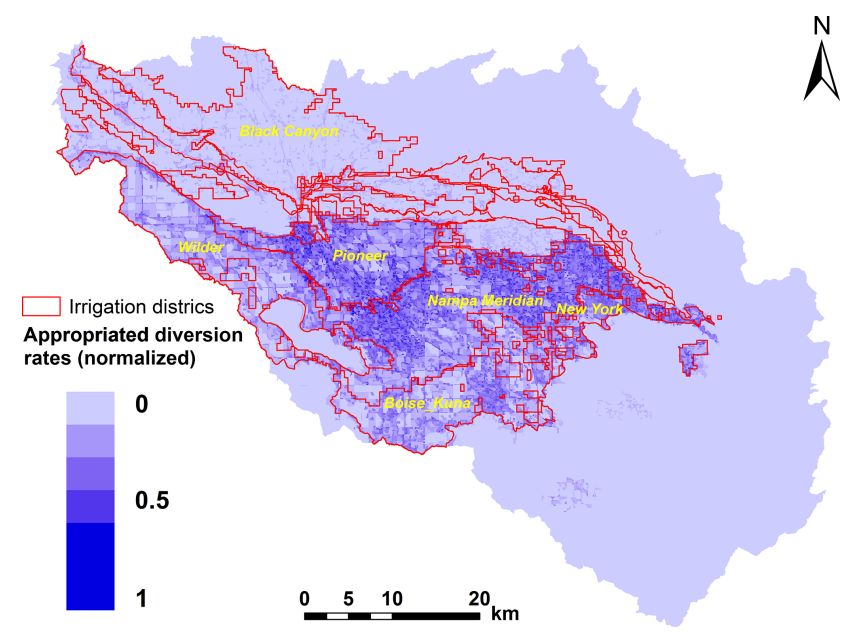

Figure 7. The annual appropriated diversion rates normalized based on water rights maximum allowed diversion rates and place of use, indicating the relative spatial distribution of potential usable water. The irrigation district boundaries and the names of major irrigation districts are also shown.

(maximum $38.21 \mathrm{~m}^{3} \mathrm{~s}^{-1}$ ), while groundwater PODs are dispersed all over the irrigated lands, usually with a relatively smaller maximum allowed diversion rate per POD (maximum $2.47 \mathrm{~m}^{3} \mathrm{~s}^{-1}$ ). Among all the surface water PODs, most surface water is mainly diverted from the Diversion Dam which connects New York Canal with the Boise River. Multiple PODs overlap at the Diversion Dam with highly senior water rights, diverting about half of the streamflow from main branch of the Boise River during the irrigation season. The diverted water provides the water resources for Lake Lowell and numerous irrigation canals downstream.

\subsection{Model-simulated spatial and temporal distribution of water use}

Comparing simulated water use with that predicted based on appropriated rates suggests the model does a good job of spatially distributing water use. The summarized appropriation rate generally matches the boundary of the irrigation districts (Fig. 7). According to the normalized appropriation rate, most of the water should be appropriated to the southwest part of the Treasure Valley, e.g., Nampa-Meridian, and the New York irrigation districts. In contrast, a relatively small amount of water should be appropriated to those areas along the Boise River and into the Black Canyon irrigation district which is located at the northwest part of the Treasure Valley.

The model-simulated allocation rate follows these spatial patterns of the appropriated rate (Fig. 8). The southwest part of the study domain receives the most allocated water, while the northwest part and the downstream section of the Boise River is allocated less water (Fig. 8).

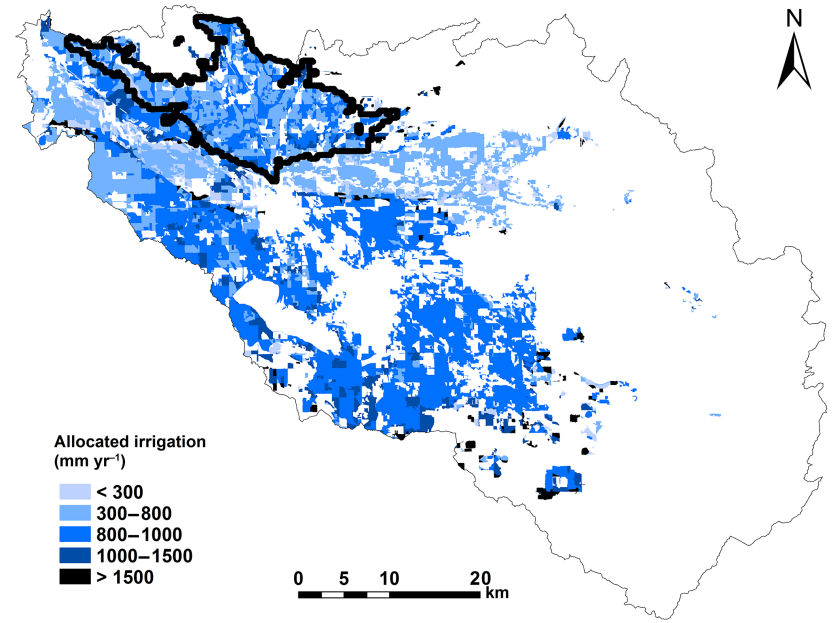

Figure 8. The spatial distribution of the annual allocated irrigation water averaged over the simulation period. The domain that is within the thick outline is the Black Canyon irrigation district, which receives additional irrigation water from outside of the domain, where the water allocation is underestimated.

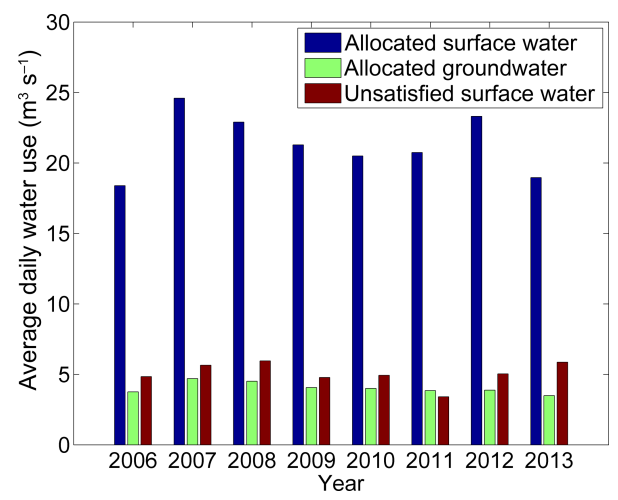

Figure 9. Average daily allocated surface water, groundwater, and unsatisfied surface water use for each year.

The simulated water allocation confirms that surface water is the main water source with regard to the amount of allocated water, as shown by the model-simulated annual and monthly allocated surface water rates, and allocated groundwater rates (Figs. 9 and 10). The allocated surface water discharge rate is $\sim 21.3 \mathrm{~m}^{3} \mathrm{~s}^{-1}$ averaged from 2006 to 2013 , while the allocated groundwater is only $\sim 4.0 \mathrm{~m}^{3} \mathrm{~s}^{-1}$.

The simulated water allocation also reflects the seasonal irrigation water use pattern. The irrigation season in the Treasure Valley occurs from April to November when precipitation is rare and temperature is high. As expected, most of the irrigation activities happen from May to October, representing over $95.6 \%$ of the annual total irrigation amount. The peak irrigation season is June-August, which irrigates $61.1 \%$ of the annual irrigation amount. 


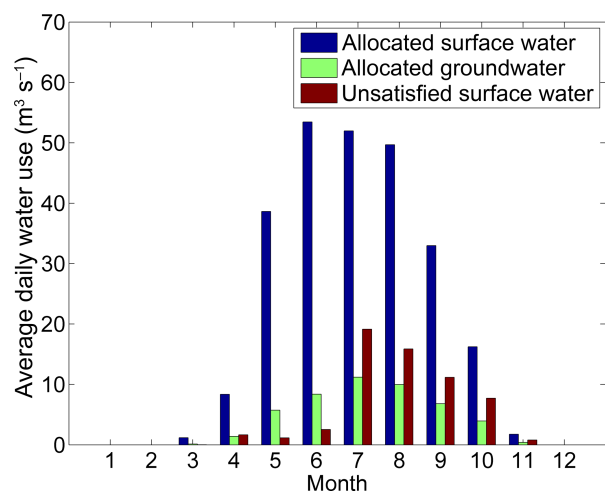

Figure 10. Average daily allocated surface water, groundwater, and unsatisfied surface water use for each month from 2006 to 2013.

\section{Discussions}

\subsection{The model's contribution to inform decision making}

\subsubsection{The model reveals water scarcity and its causes by unsatisfied water distribution}

The irrigation water scarcity is divided into four categories based on the annual unsatisfied irrigation water amount: adequate water rights $(<100 \mathrm{~mm}$ deficit), light scarcity (100$300 \mathrm{~mm}$ deficit), medium scarcity (300-600 $\mathrm{mm}$ deficit), and heavy scarcity ( $>600 \mathrm{~mm}$ deficit). There is less allocated water along the downstream section of the Boise River, which also leads to higher water scarcity in the area (Fig. 11). The northwest part of the study area experiences light to medium level water scarcity. Water scarcity is overall not serious in the Treasure Valley; however, it could pose a problem in the relatively dry years such as 2007, 2008, and 2013.

On average, $\sim 80.1 \%$ irrigation demand could be satisfied from 2006 to 2013, with an unsatisfied irrigation rate about $5.1 \mathrm{~m}^{3} \mathrm{~s}^{-1}$ for the whole irrigation area. However, the unsatisfied irrigation amount varies greatly between years. For example, in 2011, when the annual precipitation was higher than normal (Fig. 12), only an annual average of $3.4 \mathrm{~m}^{3} \mathrm{~s}^{-1}$ irrigation amount was unsatisfied in the Treasure Valley, while in 2013, when the annual precipitation was lower than normal, the annual averaged unsatisfied irrigation amount doubled to about $5.9 \mathrm{~m}^{3} \mathrm{~s}^{-1}$ (Fig. 9). The Mediterranean climate pattern produces dry and hot summers which, even in the wettest years, have some degree of unmet water potential irrigation use.

While the water rights appropriation rate reflects the irrigation district regulation, the allocated rate also considers the biophysical demand and has the capacity to reveal where the current water rights are not sufficient for biophysical use. For example, the areas along the downstream Boise River experience a relatively higher water scarcity (Fig. 11). Since the Boise River has abundant water to extract during the irriga-

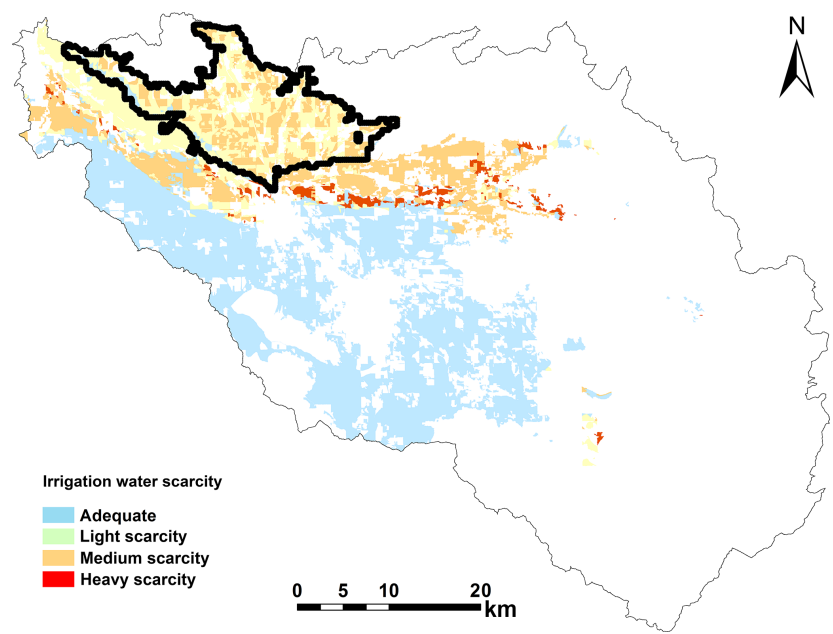

Figure 11. The spatial distribution of the annual unsatisfied irrigation maps averaged over the simulation period. The domain that is within the thick outline is the Black Canyon irrigation district, which receives additional irrigation water from outside of the domain, where the water scarcity is overestimated.

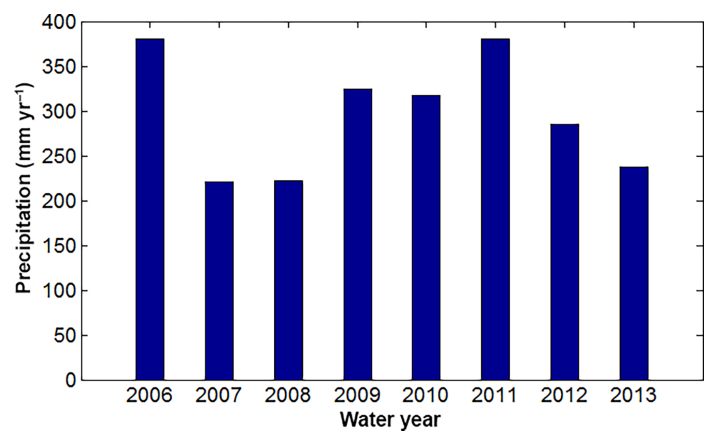

Figure 12. Annual precipitation amount calculated at Boise Air Terminal (station ID: 7268104131). Precipitation is calculated based on water year since irrigation in each calendar year is mainly affected by the precipitation during the spring and previous winter.

tion season, as shown in the discharge figures (Fig. 4), the water scarcity is mainly due to the water rights constraints. While this area is ascribed to be agricultural land, the area is mainly used for grass/pasture (Fig. 13), which does not require much irrigation. Should these areas be converted to irrigated agricultural lands, they will need a larger water right allocation to support crops. This illustrates the value of spatially explicit demand-based water allocation and associated patterns to understand the irrigation water use dynamics.

\subsubsection{The model indicates irrigation inefficiency through the simulation of demand-based water allocation and the actual water use}

Demand-based water allocation rates and the actual water use vary significantly. The allocated water in an IDU is determined by the IDU water demand, the water availability 


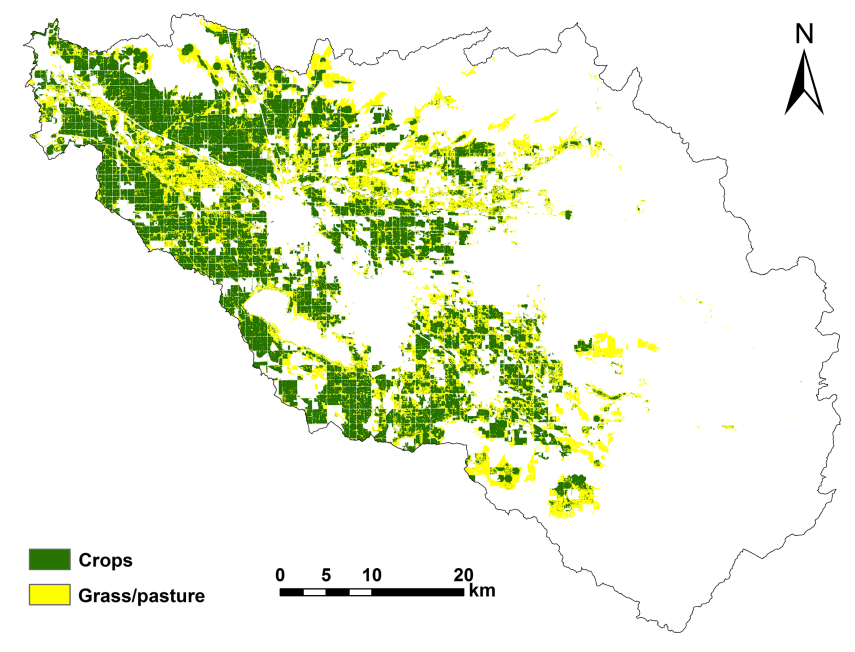

Figure 13. The spatial distribution of crops and grass/pasture in the agricultural area of the Treasure Valley.

in the stream, and the water rights allocation rate and priority. The IDU water demand is calculated for irrigated lands based on the potential ET rates and the water loss coefficient. However, the actual water use by the farmers is usually more arbitrary, relying on their experience, their irrigation methods, and the economic expectations, and is a complex function. Application efficiencies for traditional furrow-irrigated systems supplied by siphon tubes or gated pipes range between 30 and $40 \%$, with efficiencies of $50-60 \%$ possible with excellent management (Neibling, 1997). A large amount of water is wasted even in this water-limited environment. The simulated multi-year average of allocated surface water is $\sim 0.6 \mathrm{~m}$. This number is in the lower range of the allotted irrigation water by the Boise Project Board of Control which is about $0.6-0.9 \mathrm{~m}$ in normal years for farmer use. This can also be validated by the diverted amount of water from the New York Canal (Fig. 5), with an overall slight underestimation but very good match between simulations and observations (correlation coefficient of 0.92). Considering that the water release at the operational level normally relaxes the biophysical demands and varies annually, our simulated irrigation water amount is in the right scale.

\subsection{Model limitations}

While the model appears to be an effective tool to express spatially explicit water-rights-based allocation, there are some important features not captured by the model. Specifically, during the dry years, e.g., 2007 and 2013, the model produces higher simulated discharge compared to the observations at the Parma River gage during the irrigation season. There are a number of reasons for these deviations in the model: (1) groundwater use is currently assumed to be unlimited, leading to extra amount of water recharged into the soil layer. Although this reflects the current groundwa- ter abundance of the study area, it does not maintain the water balance after groundwater irrigation, and may lead to larger simulated stream discharge downstream of the irrigation area. However, since groundwater irrigation counts for a very small portion of the irrigation water use, we intend to simplify the model at this stage by assuming an unlimited groundwater supply. (2) The diversion of water in many canals is actually operated as constant flows, differing from the demand-need diversion rates of the model. As such, it is implausible to find a perfect match between observations and simulations. (3) The model is limited to the Boise River watershed and only water within that watershed is considered. However, there is some transfer into the basin from the adjacent watershed. This is especially important for the northwest part of the Treasure Valley (mainly the Black Canyon irrigation district) where the model predicts water scarcity (Fig. 11). In reality, some water is pumped from Payette River outside of the boundary to irrigate this area so it is very likely that the model is underestimating the water allocation and exaggerating the water scarcity in this area. (4) The model is semi-conceptual and ignores some minor consumptive water use, e.g., the water that is incorporated into products or crops, consumed by humans or livestock, or otherwise removed from the immediate water environment.

A second area where the model underperforms captures some flow details at the beginning of each year. Local agencies tend to empty the reservoirs in the winter time for spring flood protection, while the model ignores this local human operation. In addition, irrigation water use is not only affected by weather conditions and irrigation at the current time step but also affected by a longer-term climate and surrounding environments. Considering that the surface water source is mainly from snowmelt in the upper Boise River basin, the available water of an irrigation season in the study area is strongly affected by the precipitation from the current spring and the previous winter in the upper watershed. As such, the annual summation of the allocated water is complex and has no linear relationship with the annual precipitation amount. For example, 2007 was a dry year, but the allocated water was still relatively high (Fig. 9) due to the high precipitation rate in 2006 (Fig. 12) which released abundant snowmelt from the upper watershed during the earlier irrigation season of 2007.

Nonetheless, Boise River has never been totally drained out in a single day during the simulation period and has abundant water to be diverted. The river joins the Snake River and then flows north towards mostly public lands. While accurate simulation of water diversion is important in the Treasure Valley, it is not critical further downstream for either human use due to the low population size or environmental protection due to the relative abundance of water in the Snake River in Oregon and Washington. More accurate discharge downstream (e.g., at the Parma station) matching the historical record is not a deciding factor for irrigation activities in the Treasure Valley, and the downstream water balance 
mismatch is currently not an influencing factor for irrigation distribution.

Despite the limitations and challenges, the results generated by this research have successfully integrated irrigation activities into a hydrological model and can serve as a good start for further studies. The current study also proves that the integrated modeling work can provide sufficient spatial and temporal details to nevertheless provide useful insights into possible management strategies for water use in the Treasure Valley.

\subsection{Insights and future work}

This work is built under a larger ongoing modeling framework that aims to integrate complex social and biophysical processes and reveals the requirement of multidisciplinary cooperation.

Our experience suggests that deploying such an interdisciplinary approach is by no means a trivial task. During our research, a large team of scientists, engineers, and stakeholders continuously discussed and constructed an agreement on the study domain which reflected both the watershed boundary and political boundary, the research questions, the temporal scales, and the complexity of the work. Knowledge from local stakeholders was also borrowed to help justify the design of the model. This research effort is an important step forward towards the solution to the cultural and historical barriers to the integration across disciplines (Hamilton et al., 2015).

In this paper, we are using historical downscaled climate data to represent the climate, and the parameter set is only suitable for this specific case. For the future research of water availability projection, a suite of different climate change scenarios will be incorporated. Future modeling of this method will highlight changes in water deficits over time by dynamically simulating IDU water demand and water availability. Water rights are also going to be dynamically allocated with adoptive strategies when water scarcity is more severe. Other important factors such as urban growth, land use and land cover change, and crop choice will also be integrated into the future model with the feedback of stakeholders. In addition, the decision making of stakeholders has its own complexity and has to be simplified in the current model (Noël and Cai, 2017). The heterogeneity of decision making, which is often overlooked due to lack of data, has important implications and deserves better representation.

\section{Conclusion}

This study integrates spatially and temporally explicit irrigation activities into hydrologic cycles, connecting agriculture, water rights and hydrologic processes in the semi-arid Treasure Valley. The model results reveal the spatial and temporal patterns of irrigation water use and areas where current water rights are not always able to support irrigation demand. The model is useful in that it can be used to diagnose places of use and times where allocated water is likely insufficient to meet agricultural water demands and inform future water management decisions. The modeling framework is extensible and allows not only for the model to be subjected to future scenarios of urbanization and climate change but also as a tool for evaluating alternative future scenarios of water management policies and actions. The model also indicates the current knowledge gap in water use between the water-rightsbased diversion rate and the actual irrigation water consumption, including the complexity of human activities and the inability to fully capture the discharge over dry years.

Data availability. The input data for the paper can be downloaded from the links listed in Table 1 . The output data for this paper are available for download at https://doi.org/10.18122/B2S705 (Han et al., 2017).

Author contributions. ANF and BH designed the research and interpreted the results. JB and KBV provided technical support with debugging help. BH prepared the paper, with the help with SB and $\mathrm{ANF}$, and obtained agreement for submission from all coauthors.

Competing interests. The authors declare that they have no conflict of interest.

Acknowledgements. This publication was made possible by the NSF Idaho EPSCoR Program and by the National Science Foundation under award no. IIA-1301792. Coauthors were also supported by NSF EAR-1011912. We appreciate the help of James Sulzman and Cynthia Schwartz during the modeling processes.

Edited by: Murugesu Sivapalan

Reviewed by: three anonymous referees

\section{References}

Abatzoglou, J. T. and Brown, T. J.: A comparison of statistical downscaling methods suited for wildfire applications, Int. J. Climatol., 32, 772-780, 2012.

Abebe, N. A., Ogden, F. L., and Pradhan, N. R.: Sensitivity and uncertainty analysis of the conceptual HBV rainfall-runoff model: Implications for parameter estimation, J. Hydrol., 389, 301-310, 2010.

Ahrends, H., Mast, M., Rodgers, C., and Kunstmann, H.: Coupled hydrological-economic modelling for optimised irrigated cultivation in a semi-arid catchment of West Africa, Environ. Model. Softw., 23, 385-395, 2008.

Allen, R. G. and Robison, C. W.: Evapotranspiration and consumptive irrigation water requirements for Idaho. IDWR, Research Technical Completion Report, University of Idaho, avail- 
able at: http://www.ecy.wa.gov/programs/wr/wig/images/pdf/et_ cir_wa_102008.pdf (last access: 20 June 2017), 2007.

Allen, R. G., Pereira, L. S., Raes, D., and Smith, M.: Crop evapotranspiration-Guidelines for computing crop water requirements-FAO Irrigation and drainage paper 56, FAO, Rome, 300, p. D05109, 1998.

Barros, A., Ager, A., Preisler, H., Day, M., Spies, T., and Bolte, J.: Understanding coupled natural and human systems on fire prone landscapes: integrating wildfire simulation into an agent based planning system, paper presented at EGU General Assembly Conference Abstracts, Vienna, Austria, 2015.

Bergström, S.: The HBV Model, in: Computer Models of Watershed Hydrology, Water Resources Publications, edited by: Singh, V. P., Highlands Ranch, Colorado, 443-476,1995.

Bolte, J. P. and Vache, K. B.: Envisioning Puget Sound Alternative Futures, Oregon State University, Oregon, 2010.

Bolte, J. P., Hulse, D. W., Gregory, S. V., and Smith, C.: Modeling biocomplexity-actors, landscapes and alternative futures, Environ. Model. Softw., 22, 570-579, 2007.

Cai, W. J., Zhang, L. L., Zhu, X. P., Zhang, A. J., Yin, J. X., and Wang, H.: Optimized reservoir operation to balance human and environmental requirements: A case study for the Three Gorges and Gezhouba Dams, Yangtze River basin, China, Ecol. Inform., 18, 40-48, 2013.

Cai, X., Cui, Y., Dai, J., and Luo, Y.: Local storages: the impact on hydrology and implications for policy making in irrigation systems, Water Int., 37, 395-407, 2012.

Dam, V. J. C., Huygen, J., Wesseling, J. G., Feddes, R. A., Kabat, P., v. Walsum, P. E. V., Groenendijk, P., and v. Diepen, C. A.: Theory of SWAP version 2.0, Simulation of water flow, solute transport and plant growth in the Soil-Water-Atmosphere-Plant environment, Technical Document, No. 71, DLO Winand Staring Centre, 1997.

Döll, P. and Siebert, S.: Global modeling of irrigation water requirements, Water Resour. Res., 38, 8.1-8.10, https://doi.org/10.1029/2001WR000355, 2002.

Droogers, P., Bastiaanssen, W. G. M., Beyazgül, M., Kayam, Y., Kite, G. W., and Murray-Rust, H.: Distributed agro-hydrological modeling of an irrigation system in western Turkey, Agr. Water Manage., 43, 183-202, 2000.

Falkenmark, M.: Adapting to climate change: towards societal water security in dry-climate countries, Int. J. Water Resour. Dev., 29, 123-136, 2013.

Ferguson, I. M. and Maxwell, R. M.: Human impacts on terrestrial hydrology: climate change versus pumping and irrigation, Environ. Res. Lett., 7, 044022, https://doi.org/10.1088/17489326/7/4/044022, 2012.

Gassman, P. W., Williams, J. R., Benson, V. W., Izaurralde, R. C., Hauck, L. M., Jones, C. A., Atwood, J. D., Kiniry, J. R., and Flowers, J. D.: Historical development and applications of the EPIC and APEX models, Center for Agricultural and Rural Development, Iowa State University, Ames, 2005.

Girard, C., Rinaudo, J.-D., Pulido-Velazquez, M., and Caballero, Y.: An interdisciplinary modelling framework for selecting adaptation measures at the river basin scale in a global change scenario, Environ. Model. Softw., 69, 42-54, 2015.

Gisser, M. and Mercado, A.: Integration of the agricultural demand function for water and the hydrologic model of the Pecos basin, Water Resour. Res., 8, 1373-1384, 1972.
Gupta, H. V., Sorooshian, S., and Yapo, P. O.: Toward improved calibration of hydrologic models: Multiple and noncommensurable measures of information, Water Resour. Res., 34, 751-763, 1998.

Hamilton, S. H., ElSawah, S., Guillaume, J. H. A., Jakeman, A. J., and Pierce, S. A.: Integrated assessment and modelling: overview and synthesis of salient dimensions, Environ. Model. Softw., 64, 215-229, 2015.

Han, B., Benner, S. G., Bolte, J. P., Vache, K. B., and Flores, A. N.: Data Associated with "Coupling Biophysical Processes and Water Rights to Simulate Spatially Distributed Water Use in an Intensively Managed Hydrologic System”, Data set, https://doi.org/10.18122/B2S705, 2017.

Hutchins, W. A.: Water Rights Laws in the Nineteen Western States, Natural Resource Economics Division, Economic Research Service, United States Department of Agriculture, Washington, DC, 1977.

Huter, L. R., Mahler, R. L., Brooks, L. E., Lolley, B. A., and Halloway, L.: Groundwater and wellhead protection in the HUA, UI Bull. 811, Univ. of Idaho, Moscow, 1999.

IDWR: Treasure Valley Groundwater Model, Idaho Department of Water Resources, available at: https://www.idwr. idaho.gov/WaterInformation/Projects/tvhp-revised/, last access: 20 June 2017.

Inouye, A. M.: Development of a hydrologic model to explore impacts of climate change on water resources in the Big Wood Basin, Idaho, PhD Dissertation, Oregon State University, Oregon, 2014.

Jakeman, A. J. and Letcher, R. A.: Integrated assessment and modelling: features, principles and examples for catchment management, Environ. Model. Softw., 18, 491-501, 2003.

Kirby, J. M., Mainuddin, M., Ahmad, M. D., and Gao, L.: Simplified monthly hydrology and irrigation water use model to explore sustainable water management options in the Murray-Darling Basin, Water Resour. Manage., 27, 4083-4097, 2013.

Laniak, G. F., Olchin, G., Goodall, J., Voinov, A., Hill, M., Glynn, P., Whelan, G., Geller, G., Quinn, N., and Blind, M.: Integrated environmental modeling: a vision and roadmap for the future, Environ. Model. Softw., 39, 3-23, 2013.

Lawrence, D., Haddeland, I., and Langsholt, E.: Calibration of HBV hydrological models using PEST parameter estimation, Norwegian Water Resources and Energy Directorate, Oslo, Norway, 2009.

Leng, G., Huang, M., Tang, Q., Gao, H., and Leung, L. R.: Modeling the effects of groundwater-fed irrigation on terrestrial hydrology over the conterminous United States, J. Hydrometeorol., 15, 957-972, 2014.

Liu, J., Williams, J. R., Zehnder, A. J. B., and Yang, H.: GEPIC - modelling wheat yield and crop water productivity with high resolution on a global scale, Agricult. Syst., 94, 478-493, 2007.

Montes de Oca Munguia, O., Harmsworth, G., Young, R., and Dymond, J.: The use of an agent-based model to represent Māori cultural values, 18 th World IMACS/MODSIM Congress, Cairns, 13-17 July 2009, p. 217, 2009.

Neibling, H.: Irrigation systems for Idaho agriculture, University of Idaho, College of Agriculture, Cooperative Extension System, Agricultural Experiment Station, Idaho, 1997.

Noël, H. and Cai, X.: On the role of individuals in models of coupled human and natural systems: Lessons from a case study in 
the Republican River Basin, Environ. Model. Softw., 92, 1-16, 2017.

Pahl-Wostl, C.: Transitions towards adaptive management of water facing climate and global change, Water Resour. Manage., 21, 49-62, https://doi.org/10.1016/j.envsoft.2017.02.010, 2007.

Petrich, C. R.: Simulation of ground water flow in the lower Boise River Basin, Idaho Water Resources Research Institute, Idaho, 2004a.

Petrich, C. R.: Treasure Valley hydrologic project executive summary, Idaho Water Resources Research Institute, Idaho, 2004b.

Sælthun, N. R.: The Nordic HBV model, Norweg. Water Resour. Energy Admin. Publ., 7, 1-26, 1996.

Seibert, J.: Estimation of parameter uncertainty in the HBV model, Hydrol. Res., 28, 247-262, 1997.

Shiklomanov, I. A.: Appraisal and assessment of world water resources, Water Int., 25, 11-32, 2000.

Sorooshian, S., Li, J., Hsu, K. L., and Gao, X.: Influence of irrigation schemes used in regional climate models on evapotranspiration estimation: Results and comparative studies from California's Central Valley agricultural regions, J. Geophys. Res.Atmos., 117, D06107, https://doi.org/10.1029/2011JD016978, 2012.

SSURGO Database: Natural Resources Conservation Service, available at: https://www.nrcs.usda.gov/wps/portal/nrcs/detail/ soils/survey/?cid=nrcs142p2_053627, last access: 20 June 2017.

Stöckle, C. O., Donatelli, M., and Nelson, R.: CropSyst, a cropping systems simulation model, Eur. J. Agron., 18, 289-307, 2003.

Stöckle, C. O., Kemanian, A. R., Nelson, R. L., Adam, J. C., Sommer, R., and Carlson, B.: CropSyst model evolution: from field to regional to global scales and from research to decision support systems, Environ. Model. Softw., 62, 361-369, 2014.
Turner, D. P., Conklin, D. R., and Bolte, J. P.: Projected climate change impacts on forest land cover and land use over the Willamette River Basin, Oregon, USA, Climatic Change, 133, 335-348, 2015.

Urban, S. M. and Petrich, C. R.: water budget for the Treasure Valley aquifer system, Treasure Valley Hydrologic Project Research Report, Idaho Department of Water Resources, Boise, Idaho, 1996.

Vörösmarty, C. J., Green, P., Salisbury, J., and Lammers, R. B.: Global Water Resources: Vulnerability from Climate Change and Population Growth, Science, 289, 284-288, 2000.

Willaarts, B. A., Volk, M., and Aguilera, P. A.: Assessing the ecosystem services supplied by freshwater flows in Mediterranean agroecosystems, Agr. Water Manage., 105, 21-31, 2012.

Woodsmith, R. D., Vache, K. B., McDonnell, J. J., Seibert, J., and Helvey, J. D.: The Entiat Experimental Forest: a unique opportunity to examine hydrologic response to wildfire, in: Advancing the fundamental sciences: Proceedings of the Forest Service National Earth Sciences Conference, edited by: Furniss, M., Clifton, C., and Ronnenberg, K., San Diego, CA, 18-22 October 2004, 205-216, PNW-GTR 689, Portland, OR: US Department of Agriculture, Forest Service, Pacific Northwest Research Station, 2007.

Wurbs, R. A.: Texas water availability modeling system, J. Water Resour. Pl. Manage., 131, 270-279, 2005a.

Wurbs, R. A.: Modeling river/reservoir system management, water allocation, and supply reliability, J. Hydrol., 300, 100-113, 2005b.

Xu, W., Lowe, S. E., and Adams, R. M.: Climate change, water rights, and water supply: The case of irrigated agriculture in Idaho, Water Resour. Res., 50, 9675-9695, 2014. 